\title{
Importance of fish biodiversity in conservation planning of Brazilian National Parks
}

\author{
Importância da biodiversidade de peixes no planejamento da conservação dos Parques Nacionais
}

Brasileiros

Importancia de la biodiversidad de peces en la planificación de la conservación de los Parques

Nacionales Brasileños

Received: 07/27/2021 | Reviewed: 07/31/2021 | Accept: 08/01/2021 | Published: 08/06/2021

Thércia Gonçalves Ribeiro Monroe
ORCID: https://orcid.org/0000-0003-0658-0643
Universidade Estadual do Maranhão, Brazil
E-mail: tgrmonroe@outlook.com
Selma Patrícia Diniz Cantanhêde
ORCID: https://orcid.org/0000-0002-0497-8415
Universidade Estadual do Maranhão, Brazil
E-mail: patriciasdc@ @otmail.com
Natanael Bezerra Monroe
ORCID: https://orcid.org/0000-0001-7624-0869
Universidade Estadual do Maranhão, Brazil
E-mail: natanaelmonroe@ @otmail.com
Fabricio Silva Garcez
ORCID: https://orcid.org/0000-0003-3869-5701
Universidade Estadual do Maranhão, Brazil
E-mail: fabricioh6@ hotmail.com
Lígia Tchaicka
ORCID: https://orcid.org/0000-0003-1993-1377
Universidade Estadual do Maranhão, Brazil
E-mail: ltchaicka@ @ahoo.com.br

\begin{abstract}
Protected areas are essential for the maintenance of biodiversity. In Brazil, national parks encompass one of the most important portions of this area $(26.864 .003,74 \mathrm{ha})$ that needs to be adequately managed to achieve conservation. Aiming to understand how the ichthyofauna data is included in management plans of Brazilian National Parks, we review 55 Brazilian national parks management plans to compare how data of freshwater fish fauna are included in these documents. The data evaluated from management plans were Hydrography, ichthyofauna list, participation of professionals trained in rapid ecological assessment and species richness, endangered and invasive species. This information was used to categorize the management plans through two sets of assessing: quality of rapid ecological assessment and coverage of species diversity. The categorization results were assumed as an indicator of the potential for biodiversity conservation of the management plans. We compare obtained results between biomes. We were able to understand that many of the Brazilian National Parks do not have management plans, and among the plans that are prepared, the lack of essential information compromises their potential for the conservation of biodiversity. We highlight the need to improve management plans for the Caatinga parks and expand the analysis of invasive species for all biomes.
\end{abstract}

Keywords: Conservation; Management; Protected areas; Freshwater fishes.

\section{Resumo}

As áreas protegidas são essenciais para a manutenção da biodiversidade. No Brasil, os parques nacionais abrangem uma das partes mais importantes dessas áreas $(26.864 .003,74$ ha) que precisam ser manejadas de forma adequada para se alcançar a conservação. Para compreender como os dados a respeito da ictiofauna são abordados nos planos de manejo de parques nacionais brasileiros e o potencial dessas informações para a conservação, revisamos 55 planos de manejo. As variáveis utilizadas foram: plano de manejo disponível, hidrografia, dados da ictiofauna de água doce, profissionais treinados em avaliação ecológica rápida e riqueza de espécies. Além disso, dados sobre espécies ameaçadas e invasoras, usando uma matriz binária (ausência / presença). Comparamos nossas classificações com dados disponíveis na literatura especializada para cada bioma brasileiro. Pudemos apreender que muitos dos Parques Nacionais brasileiros ainda não possuem planos de manejo, e entre os planos já elaborados a falta de informações essenciais compromete seu potencial para a conservação da biodiversidade. Destacamos a necessidade de melhoria dos planos de manejo para os parques da Caatinga e a ampliação da análise de espécies invasoras para todos os biomas. 
Palavras-chave: Conservação; Gestão; Áreas protegidas; Peixes de água doce.

\section{Resumen}

Las áreas protegidas son esenciales para el mantenimiento de la biodiversidad. En Brasil, los parques nacionales abarcan una de las porciones más importantes de esta área (26.864.003,74ha) que necesita ser manejada adecuadamente para lograr la conservación. Para comprender cómo se abordan los datos sobre la ictiofauna en los planes de manejo de los Parques Nacionales de Brasil y el potencial de esta información para la conservación. revisamos 55 planes de gestión de parques nacionales brasileños para comparar cómo se incluyen en estos documentos los datos de la fauna de peces de agua dulce. Los datos evaluados de los planes de manejo fueron Hidrografía, listado de ictiofauna, participación de profesionales capacitados en valoración ecológica rápida y riqueza de especies, especies amenazadas e invasoras. Esta información se utilizó para categorizar los planes de manejo a través de dos conjuntos de evaluaciones: la calidad de la evaluación ecológica rápida y la cobertura de la diversidad de especies. Los resultados de la categorización se asumieron como un indicador del potencial de conservación de la biodiversidad de los planes de manejo. Comparamos los resultados obtenidos entre biomas. Pudimos aprehender que muchos de los Parques Nacionales brasileños aún no cuentan con planes de manejo, y entre los planes ya preparados, la falta de información esencial compromete su potencial para la conservación de la biodiversidad. Destacamos la necesidad de mejorar los planes de manejo de los parques de Caatinga y ampliar el análisis de especies invasoras para todos los biomas.

Palabras clave: Conservación; Gestión; Áreas protegidas; Peces de agua dulce.

\section{Introduction}

Protected areas (PAs) are those reserved for the preservation of biological diversity and the use of natural and cultural resources, managed by legal means (Scherl et al., 2006). Around the world, PAs are important for in situ conservation, which is fundamental to the maintenance of the integrity of species, populations and ecosystems, including traditional means of survival in the human population (Ervin, 2003, Rylands \& Brandon, 2005; Lovejoy, 2006).

Brazilian National System of Conservation Units (SNUC) (Ministry of the Environment, 2000) is the main environmental law that regulates the establishment of protected areas in Brazillian territory. National Parks (NP) are one category of PAs which are intended to contribute to the maintenance of genetic resources, providing a refuge for endemic and threatened species (Brunner et al., 2001, Le Saout et al., 2013, Coetzee et al., 2014; Ministry of the Environment, 2000a). Most PAs in Brazil are NPs that together encompass 26.864.003,74 ha of Brazillian lands (ICMBio, 2020) and include portions of all main river basins of the country. To achieve the goal of conservation, Brazillian law determines that all the PAs need to create a management plan (MP) a guide that rules the uses and actions for the area and must be implemented by the environmental agency.

The fishes are the major group among the vertebrates (Pough et al., 2008), with a total of 33,000 species (Roskov et al., 2020), that presents high diversity and degree of endemism in the neotropical region. Brazil has 2,587 species of freshwater fish, representing $43 \%$ of the species of the world (Buckup et al., 2007).

Here, we review the data available for the freshwater fish on management plans of Brazillian National Parks to understand the scope of the information contained in these documents and the employment possibilities in biological conservation.

\section{Methodology}

\subsection{Data collection}

Management plans were obtained from the databases of ICMBio (Chico Mendes Institute for Biodiversity Conservation - Brazilian Agency for Protected Areas). Data from 74 National Parks were investigated, from which 55 management plans were assessed (the others are not publicly available). Management plans were grouped by their local biome: 
Amazon (AM), Atlantic forest (AF), Cerrado (CE), Caatinga (CA), Pampa (PAM) and Pantanal (PAN) as defined in the Ministry of the Environment (2020b).

\subsection{Data analysis}

Collected data were organized in two sets of evaluation as follows:

1. Quality of rapid ecological assessment: the elaboration of each MP were compared with the criteria required in the Rapid Ecological Assessment - the official guide of Brazilian Institute of Environment and Nonrenewable Natural Resources (IBAMA, 2002) and scored/in the range: (1) No quality- MP includes only Hydrography; (2) Low quality- MP includes Hydrography, Ichthyofauna data; (3) Medium quality - MP includes hydrography, Ichthyofauna data, species richness and (4) High quality - MP includes hydrography, Ichthyofauna data, species richness and was elaborated by trained professionals (as described for each professional in the curriculum lattes of CNPQ).

2. Coverage of species diversity: absolute species diversity (number of species), in each MP were compared with data from literature review. We access articles since 2000 to compile a most complete list of fish available for each Protected Area and results were scored and expressed as: (score 1) Underestimated when $\mathrm{MP}<$ Specialized literature, (2) overestimated when MP>Specialized literature, (3) compatible when MP include the same information of specialized literature, (4) MP as the only source of data. Non-native and threatened species were also considered and compared with the specialized literature.

\section{Results}

Regarding the distribution of NP by biomes, our results demonstrate greater number of MP in the Atlantic Forest $(32 \%, 875.611,11$ ha total area) and Amazon $(28 \%, 21.411 .309,46$ ha total area) biomes, including 45 of the total parks. The other biomes presented: Cerrado (20\%, 3.612.137,96), Caatinga (10,6\%, 682.065,22 ha), Pampa (1,3\%, 176.496,00 ha) and Pantanal $(1.3 \%, 135.992,65$ ha) of the NP (Figure1).

Figure 1 - Number of national parks and management plans by biome.

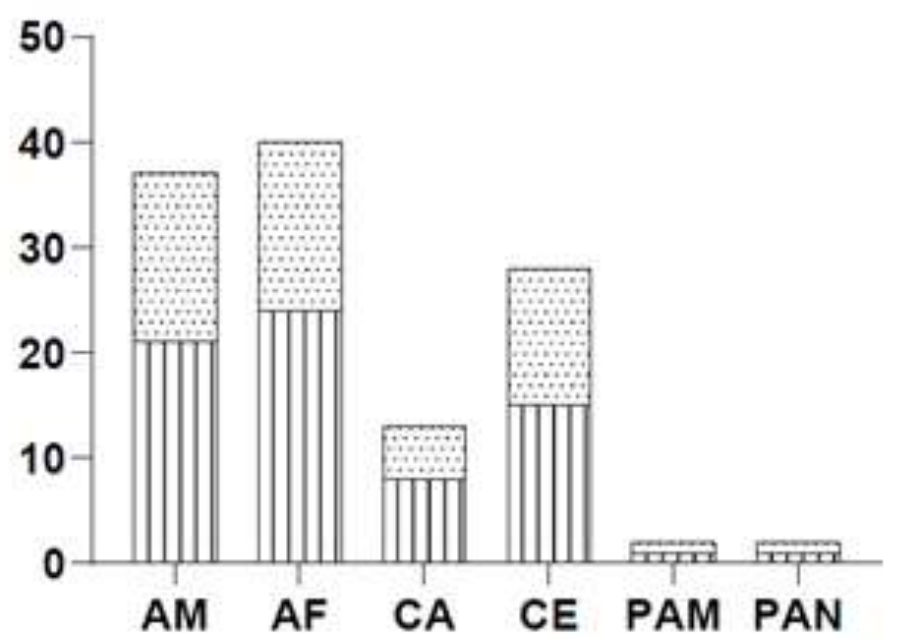

Management Plans III National Parks

$\mathrm{CA}=$ Caatinga $\mathrm{CE}=$ Cerrado; $\mathrm{AM}=$ Amazon $\mathrm{AF}=$ Atlantic Forest $\mathrm{PAM}=\mathrm{Pampa} ; \mathrm{PAN}=$ Pantanal. Source: Authors.

Considering that all National Parks included hydrographic networks, a gap was observed between the number of management plans and ichthyofauna data. Only $74.32 \%$ of the MPs present studies of ichthyofauna in their of ficial documents. 
In assessing the quality of management plans for biodiversity conservation, 41.81\% of MP was considered as high quality; $14.54 \%$ as medium quality, $3.63 \%$ low quality as, with no quality $41.81 \%$, according to set 1 .

Regarding the period of elaboration of the management plan, we found that only $52.6 \%$ of NP had it's MP in five years after the official creation. Among these MPs, $43.63 \%$ were elaborated by specialists. For the parks created before the SNUC requirement (Ministry of the Environment, 2000), the average period of MP publication was 15 years and $63.6 \%$ of than present ichthyofauna data produced by the Rapid Ecological Assessment, the others include only compilations of previously published data.

For the second set, data on species richness, $90.1 \%$ of NP do not present compatible information with inventories carried out and published for the biome: the fauna were underestimated in 30.3\% of the MP, overestimated in 33.3\%, and compatible in $9,09 \%$. For $33.3 \%$ of the NP, the PM is the only source of data available.

In the association of the sets, we observed that the management plans with high quality showed: overestimated fauna (31.8\%), underestimated (31,8\%) and 36.3\% represented the plans that are the only available data source (Fig.2).

Figure 2 - Associated distribution of management plans in the evaluated criteria (Quality of Assessment Rapid Ecology and Species Richness).

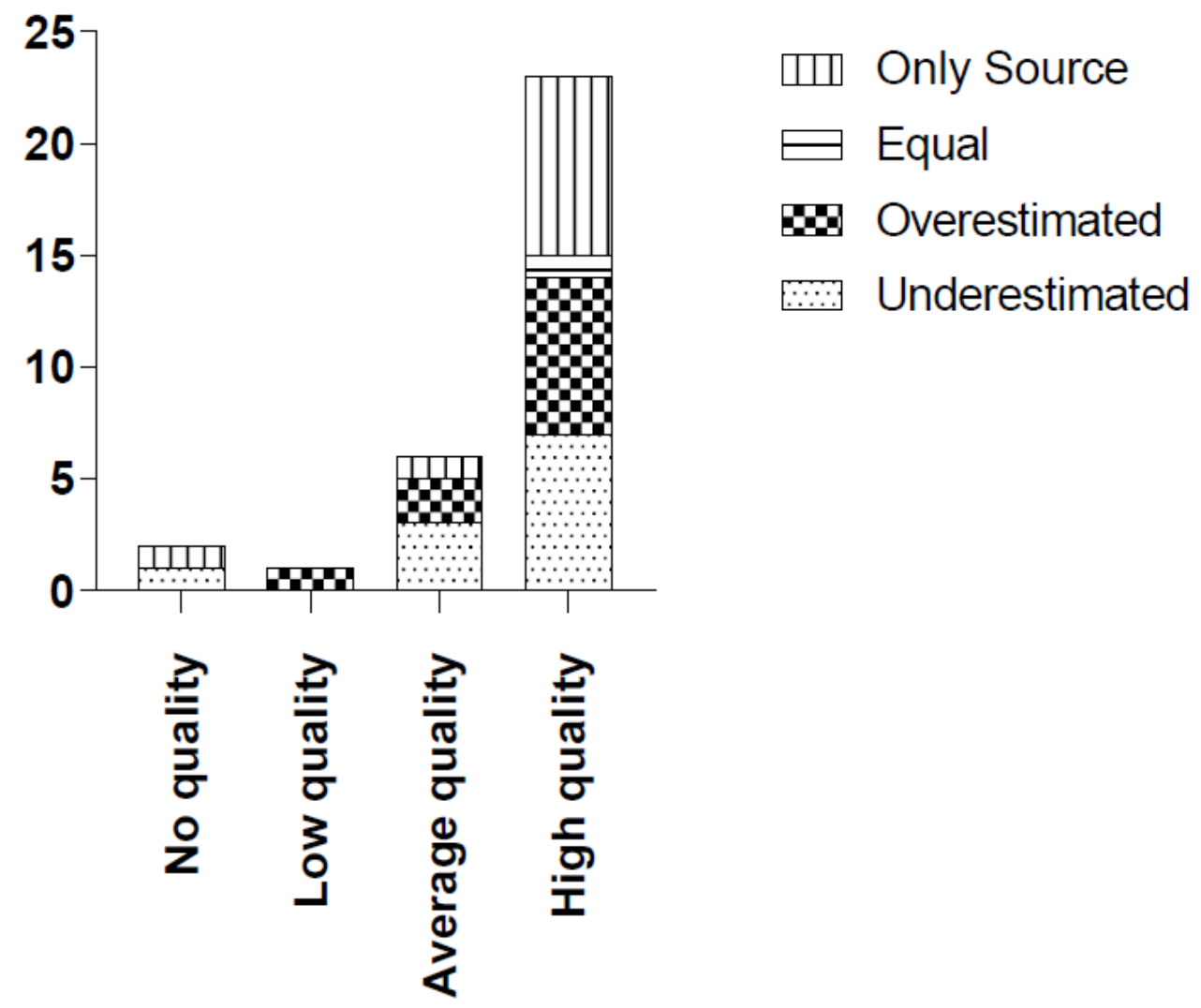

Source: Authors.

When analyzing the distribution of high quality management plans by biome, it is possible to observe the weaknesses in the caatinga and pampa areas that do not have high quality management plans. Considering the underestimated data, in the cerrado $(42.8 \%)$, in the Atlantic Forest $(28.5 \%)$, which represent the majority of its management plans, followed by the pantanal $(14.2 \%)$. 
For overestimated data, the Amazon (50\%), Cerrado (37.5\%) and Atlantic Forest (12.5\%) stand out. It is also important to highlight that for some biomes, the management plan is the only source of information about iconic biodiversity, such as the Amazon (75\%), Cerrado and Atlantic Forest (12.5\%).

The analysis of non-native and endangered species verified non-conformities between data management plans and specialized literature (Figure 3).

Figure 3 - Comparison between data obtained from management plans and specialized literature. $A=A l i e n$ species; $B=$ Threatened species

\section{A}

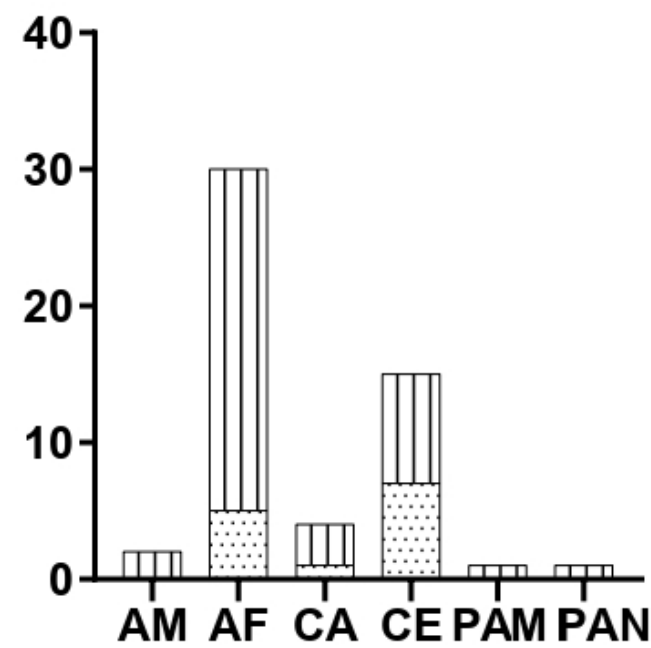

\section{एा) Literature Management plan}

B

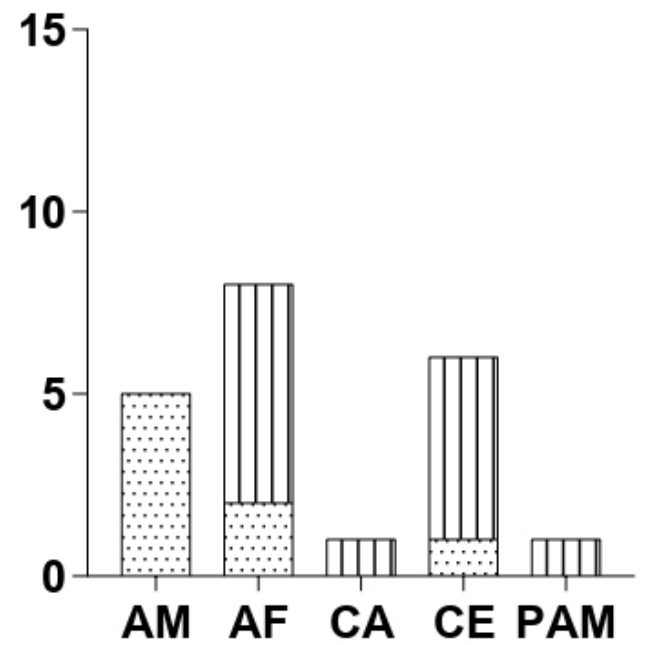

$\mathrm{CA}=$ Caatinga $\mathrm{CE}=$ Cerrado $\mathrm{AM}=$ Amazon $\mathrm{AF}=$ Atlantic Forest $\mathrm{PAM}=\mathrm{Pampa} ; \mathrm{PAN}=$ Pantanal Source: Authors. 
Management plans for 12 national parks recorded alien species, with emphasis on the Cerrado (28 species) and Atlantic Forest (12 species) biomes, followed by the Caatinga ( 5 species). For threatened, only $12.9 \%$ of the management plans include data, however, this percentage is underestimated in comparison with the specialized literature in $37 \%$ of the plans.

\section{Discussion}

Our study provides a systematic overview of the information used in the management of the ichthyofauna biodiversity in Brazilian national parks. We found that most management plans have low and medium potential for the conservation of continental fish species (63.9\%), in contrast to one of the main objectives of the NP: to protect and recover water resources and edaphic (Ministry of the Environment, 2010).

We found that $27 \%$ of National Parks do not have management plans, however, Cifuentes et al. (2000) estimate that less than $30 \%$ of protected areas in the world have a management plan. Although not ideal, considering previous studies, where 78\% of federal conservation units did not have a management plan (Ministry of the Environment 2011), there was a significant decrease in the absence of management plans, demonstrating the effort to meet the targets established in the National System of Conservation Units.

We also identified that national park management plans were drawn up an average of 15 years after creation, in contrast to what was established by the Ministry of the Environment (2000), that all conservation units must have a management plan within up to 5 years after the creation of the UC. According to Medeiros \& Araujo (2011), this gap also demonstrates a limitation in the management and implementation of protected areas.

Despite efforts to expand protected areas in Brazil that, between 2003 and 2010 the country housed $75 \%$ of the total protected area in the world (WWF, 2011), some objections to the effectiveness of these areas in relation to freshwater ichthyofauna should be considered. Our results demonstrate that, for ictic biodiversity in national parks, park planning, in its minority, has a high potential for biodiversity conservation (40\%). And when evaluating the plans with high potential by biome, we highlight the criticality in the caatinga and pampa (0\%).

The caatinga is the only biome exclusively Brazilian (IBGE, 2002), therefore, it should be one of the most effective biomes in conservation units, nonetheless, our data reveal that from eight national parks the management plans were classified in categories 1, 2 and 3 (no potential, low potential and average potential) for the conservation of ichthyofauna.

This data is worrying, given that the ichthyofauna data presented are secondary data, from a bibliographic review (145 species of fish), none of them prepared by specialists, in addition to the registration of 5 invasive species. On the other hand, when considering the study carried out by Braga (2016) that identified 255 ict species, 6 invasive species and 86 endemic species in the biome, we conclude that the data available in the management plan for managing the biome are outdated.

Considering that the biome has a high rate of endemicity (Ramos et al., 2014), and threats to iconic biodiversity, such as overfishing and dam construction, our data corroborate with Casarim, Caldeira \& Pompeu (2019) when verifying that national parks have low representativeness in the conservation of the caatinga ichthyofauna. Thus, we indicate the need to prioritize protected areas in the biome, in addition to the effort to inventory the species that occur in these areas, as well as the analysis of endemic and threatened species. As for the Amazon and Atlantic Forest biomes, our assessment showed different patterns, despite the fact that the biomes have the largest number of national parks (43) and present the same number of management plans (15).

The Amazon was also the biome that presented most of the management plans with high potential), however, for the associated analysis only $13.3 \%$ have more robust data than those available in the specialized literature, while $75 \%$ of the plans contain the only information regarding the freshwater ichthyofauna in protected areas. 
In this sense, we can verify that despite the estimate of the iconic diversity of the Amazon (c. 3000 species), proportionally, few studies are carried out in the region. Although there are inventories for the Amazon basin, data on protected areas are incipient, corroborating with Junk et al. (2001).

This has direct implications for the conservation of ecological biodiversity, since impacts in the Amazon have grown, such as the demarcation of protected areas, overfishing, and hydroelectricity. Given our data, we recommend the robust inventory and monitoring of ichthyofauna in protected Amazonian areas.

In contrast, the situation of the Atlantic Forest requires caution, both because of the history of resource exploitation and human pressure (Jones et al., 2018) and because it is considered a biodiversity hotspot (Myers et al., 2000). Despite having the largest number of protected areas, only $25 \%$ of management plans were categorized with high potential, and of these, $50 \%$ have underestimated data in relation to specialized literature.

For the associated analysis, 36.3\% of management plans with high potential in the biome present more robust and unique data for the region. This fact reflects the conditions for the proper management of the iconic freshwater species. To this end, the Chico Mendes Institute for Biodiversity Conservation (Ministry of the Environment, 2019) created the National Action Plan for the Conservation of Endangered Atlantic Forest Fish and Eglas - PAN Fish and Eglas of the Atlantic Forest, with the objective of improving the conservation status and popularize fish, eglas, rivers and streams of the Atlantic Forest, in 5 years.

Another biome considered a hotspot for biodiversity is the cerrado. For this biome, our analyzes show that in relation to the categorization referring to ERA, $69.2 \%$ of the 13 available management plans have high potential. Nevertheless, when the categorizations are combined, $44.4 \%$ have underestimated data and 50\%, more robust and unique data. The data presented here are essential for the scientific community and managers, since a biome relevant to the global biodiversity of the ichthyofauna needs monitoring and reinforcement for the inventory in protected areas, thus indicating a need for expansion and effectiveness of protected areas.

Unlike what has been exposed so far, the Pantanal biome stands out because despite having only one national park in its extension, the management plan contemplates all categories of rapid ecological assessment and has a high potential. Although when in combined analysis, diversity data are underestimated. Communicating, however, that the park management plan was published 17 years ago, indicating the need to update data.

Additionally, our data demonstrate the incipient knowledge of endangered and invasive species in Brazilian protected areas. In this context, we observed that of the 33 management plans with ichthyofauna data, $21.2 \%$ mention endangered and endemic species. However, the literature records $60.6 \%$ of the park's endangered and endemic species.

There are 312 listed endangered species in Brazil (Ministry of the Environment, 2018), so it is important to highlight the possibility of creating more protected areas to ensure the conservation of these species. For example, Nogueira et al. (2010) found that most of the endemic-restricted species detected by them are found in watersheds in the Cerrado and Atlantic forest biomes, considered global conservation priorities due to high endemism and habitat loss (Nogueira et al., 2010).

\section{Conclusion}

We conclude then that based on the data obtained here, Brazilian National Parks in general lack essential information available in management plans. And when available, in a few cases they have a high potential for the conservation of biodiversity. This indicates the need for a careful review of the management plans already prepared, in order to include updated data analyzed by experts. It is especially necessary to consider the biological invasions that are one of the main threats to native species. 
Research, Society and Development, v. 10, n. 10, e106101018769, 2021

(CC BY 4.0) | ISSN 2525-3409 | DOI: http://dx.doi.org/10.33448/rsd-v10i10.18769

\section{Acknowledgments}

The authors thank the Fundação de Amparo à Pesquisa e ao Desenvolvimento Científico e Tecnológico do Maranhão - FAPEMA for the financial support.

\section{Funding}

Fundação de Amparo à Pesquisa e ao Desenvolvimento Científico e Tecnológico do Maranhão - FAPEMA.

\section{References}

Braga, M. E. (2016). Check list da ictiofauna de água doce da Caatinga.

Brunner, A. G., Gullison, R. E., Rice, R. E., \& Da Fonseca, G. A. (2001). Effectiveness of parks in protecting tropical biodiversity. Cience, 291(5501), 125128.

Buckup, P. A., Menezes, N. A., \& Ghazzi, M. S. A. (2007). Catálogo das espécies de peixes de água doce do Brasil (Vol. 23). Rio de Janeiro: Museu Nacional.

Casarim, R., Caldeira, Y. M., \& Pompeu, P. S. (2020). Representativeness of national parks in protecting freshwater biodiversity: A case of Brazilian savanna. Ecology of Freshwater Fish, 29 (4), 705-721.

Cifuentes, M., Izurieta, A., \& de Faria, H. H. (2000). Medición de la efectividad del manejo de áreas protegidas. WWF.

Coetzee, B. W., Gaston, K. J., \& Chown, S. L. (2014). Local scale comparisons of biodiversity as a test for global protected area ecological performance: a meta-analysis. PloS one, 9(8), e105824.

Ervin, J. (2003). Avaliação rápida da eficácia da gestão de áreas protegidas em quatro países. BioScience, 53 (9), 833-841.

IBAMA - Instituto Brasileiro do Meio Ambiente e dos Recursos Naturais Não Renováveis, (2002). Roteiro metodológico de planejamento: Parque Nacional, Reserva Biológica e Estação Ecológica. Brasília, Brasil: MMA.

ICMBio - Instituto Chico Mendes de Conservação da Biodiversidade (2020). Coordenação Geral de Criação, Planejamento e Avaliação de Unidades de Conservação de Brasília, Brasil: MMA.

Jones, K. R., Venter, O., Fuller, R. A., Allan, J. R., Maxwell, S. L., Negret, P. J., \& Watson, J. E. (2018). One-third of global protected land is under intense human pressure. Science, 360(6390), 788-791.

Junk, W. J., \& Soares, M. G. M. (2001). Freshwater fish habitats in Amazonia: state of knowledge, management, and protection. Aquatic Ecosystem Health \& Management, 4(4), 437-451.

Le Saout, S., Hoffmann, M., Shi, Y., Hughes, A., Bernard, C., Brooks, T. M., ... \& Rodrigues, A. S. (2013). Protected areas and effective biodiversity conservation. Science, 342(6160), 803-805.

Lovejoy, T. E. (2006). Protected areas: a prism for a changing world. Trends in Ecology \& Evolution, 21(6), 329-333.

Medeiros, R., \& Araújo, F. F. S. (Eds.). (2011). Dez anos do Sistema Nacional de Unidades de Conservação da Natureza: lições do passado, realizações presentes e perspectivas para o futuro. Ministério do Meio Ambiente.

Ministério do Meio Ambiente (2010) Gestão da Biodiversidade Aquática e Recursos Pesqueiros. Panorama da conservação de dois ecossistemas costeiros e marinhos no Brasil. Brasília, Brasil: MMA.

Ministério do Meio Ambiente (2018). Instituto Chico Mendes de Conservação da Biodiversidade. Livro Vermelho da Fauna Brasileira Ameaçada de Extinção: Volume I 492p. https://www.icmbio.gov.br/portal/images/stories/comunicacao/publicacoes/publicacoes-diversas/livro_vermelho_2018_vol1.pdf

Ministério do Meio Ambiente (2019). Instituto Chico Mendes de Conservação da Biodiversidade. Portaria No- 370 , de 1 de agosto de 2019 de aprovação do Plano de Ação Nacional para a Conservação de Espécies de Peixes e Eglas Ameaçados de Extinção da Mata Atlântica - PAN Peixes e Eglas da Mata Atlântica. Ministério do Meio Ambiente, Brasília; 2019. http://www. in.gov.br/web/dou/-/portaria-n-370-de-1- de-agosto-de-2019-209274364 acesso 26 jan 2020

Ministério do Meio Ambiente (2020a). Sistema Nacional de Unidades de Conservação da Natureza. Lei №.9.985, de 18 de julho de 2000.

Ministério do Meio Ambiente (2020b). Biomas. Digital resource at https://www.mma.gov.br/biomas.html

Myers, N., Mittermeier, R. A., Mittermeier, C. G., Da Fonseca, G. A., \& Kent, J. (2000). Biodiversity hotspots for conservation priorities. Nature, 403(6772), 853-858.

Nogueira, C., Buckup, P. A., Menezes, N. A., Oyakawa, O. T., Kasecker, T. P., Ramos Neto, M. B., \& da Silva, J. M. C. (2010). Restricted-range fishes and the conservation of Brazilian freshwaters. PloS one, 5(6), e11390. 
Research, Society and Development, v. 10, n. 10, e106101018769, 2021

(CC BY 4.0) | ISSN 2525-3409 | DOI: http://dx.doi.org/10.33448/rsd-v10i10.18769

Pough, F. H., Janis, C. M., \& Heiser, J. B. (2008). A Vida dos Vertebrados. $4^{\mathrm{a}}$ edição. São Paulo: Atheneu, $684 p$.

Ramos, TPA, Ramos, RTDC, \& Ramos, SAQ (2014). Ictiofauna da bacia do rio Parnaíba, nordeste do Brasil. Biota Neotropica, 14.

Roskov, Y., G. Ower, T. Orrell., Nicolson, D., N. Bailly, P.M. Kirk, T. Bourgoin, R.E. DeWalt, W. Decock, E. Nieukerken, J. Zarucchi \& L. Penev, L. (2019). Species 2000 \& ITIS Catalogue of Life, 2019 Annual Checklist. Digital resource at www.catalogueoflife.org/annual-checklist/2019. Species 2000: Naturalis, Leiden, the Netherlands. ISSN 2405-884X.

Rylands, A. B., \& Brandon, K. (2005). Brazilian protected areas. Conservation biology, 19(3), 612-618.

Savage, J. M. (1995). Systematics and the biodiversity crisis. BioScience, 45(10), 673-679.

Scherl, L. M., Wilson, A., Wild, R., Blockhus, J., Franks, P., McNeely, J. A., \& McShane, T. O. (2006). As áreas protegidas podem contribuir para a redução da pobreza. Oportunidades e limitações. Reino Unido: IUCN, 60.

World Wildlife Fund-Brazil (2011). Relatório Anual $2010 \quad$ WWF- Brazil. Digital resource at https://d3nehc6y19qzo4.cloudfront.net/downloads/relatorio_anual_wwf_brasil_2010__internet.pdf 